\title{
Ilona Chylińska
}

Instytut Literaturoznawstwa Uniwersytet Śląski w Katowicach e-mail: imw.chylinska@gmail.com ORCID: 0000-0002-4571-2170

\section{„Na skarpie map i pism”. Kilka uwag na marginesie twórczości Michała Książka}

Mapy są zawsze początkiem ${ }^{1}$, kuszą swoich czytelników tajemnicą, obiecując im "gotowe miejsce akcji” "2, w którym to "graficzne rzeczowniki [...] nabierają dynamiki, stają się czynnościami" ${ }^{3}$. Góra, rzeka, las - jedne z wielu statycznych symboli na mapie - w rzeczywistości prowokują ruch, dynamikę, stając się przeszkodami, do pokonania których potrzebny jest wysiłek. Mogą również oznaczać miejsce chwilowego odpoczynku, pozwalającego na inny ogląd świata (rzeczywistego, jak i tekstowego). Realny przedmiot (zadrukowana karta papieru) i nierzeczywistą opowieść konstytuuje swoisty ruch palcem po mapie. I jak zauważa Zbigniew Kadłubek:

To, co się dzieje z palcem wskazującym, dotykającym mapę [...] wpływa na wyobraźnię, nie pozostając obojętnym na sprawy ontologii. Musi się dotknąć kolorowych i zmysłowych plam na mapie lub czerwonawej blizny. Nie tylko oczami, lecz także ręką. Żeby zbadać miejsce, żeby odczuć je somatycznie, zmysłowo ${ }^{4}$.

\footnotetext{
1 Należy mieć jednak na uwadze, zwłaszcza w dalszej części niniejszego szkicu, że samo pojęcie „mapy”, na co już inni zwrócili uwagę, jest wyrażeniem nieostrym, zwłaszcza wtedy, gdy uwzględnimy $\mathrm{w}$ swym namyśle takie pojęcia jak: mapa myśli, mapa mentalna, mapa nieba czy też mapa genetyczna itd. Zob. A. Niewiadomski, Mapa. Prolegomena, Lublin 2012; E. Rybicka, Mapy. Od metafory do kartografii krytycznej, w: tejże, Geopoetyka. Przestrzeń i miejsce we wspótczesnych teoriach i praktykach literackich, Kraków 2014, s. 142-168.

2 M. Książek, Kiedy rzeka mówi: wypij mnie, „Książki” 2018, nr 6, s. 48.

3 Tamże.

4 Z. Kadłubek, Mapa, czyli świat na wynos, "Znak” 2018, nr 758-759, s. 11.
} 
Ten wędrujący po barwnej karcie palec łączy tym samym ruch pozornie statycznej mapy ${ }^{5}$ i ruch myśli w kierunku opowieści, wszak każda opowieść przenosi nas $\mathrm{w}$ inne, często nieznane nam wcześniej miejsca, a czasami stwarza je na nowo - nadpisując lub kreując zupełnie nowe "lądy niebyłe"6. Wystarczy jedno spojrzenie na mapę, by zorientować się, że i nasza opowieść będzie miała miejsce: „za siedmioma górami, za siedmioma lasami...”. Tym samym mapa staje się synonimem i przedmiotem zdrady. Jej wyciągnięcie i rozłożenie jest nieodwracalnym gestem, mówiącym: „nie jestem stąd", a więc przyznaniem się i zarazem przyjęciem na siebie etykiety obcego, kogoś spoza, kto potrzebuje „przewodnika”, by poznać przestrzeń, która jawi się jako obca, tajemnicza, niezrozumiała ${ }^{7}$. W sposób analogiczny mapa dokonuje zdrady względem terytorium, bowiem odsłania i ukazuje je $\mathrm{w}$ "pełnej okazałości" przed oczami przybysza, czyniąc go być może nawet lepiej zorientowanym $\mathrm{w}$ topografii obcej przestrzeni. Jak ma to miejsce choćby $\mathrm{w}$ dialogu poniższym:

Pytam o Niagarę.

- A tak, zobaczysz ją, zobaczysz, ona tu jest blisko.

- A jezioro?

Oluta dziwi się.

- Jezioro?

- No, zanim tu przyjechałem do Ameryki, to oglądałem wasze miasto na mapie i myślałem, że ono jest nad jeziorem.

- Tak? - dziwi się Oluta.

$\mathrm{Na}$ to odwraca się od biurka Elek.

- No jak to? Nie wiesz, że mieszkamy nad jeziorem?

- Tak? Buffalo jest nad jeziorem? Nie wiedziałam.

- Jak to nie wiedziałaś? Mieszkamy tu dwanaście lat.

- No, nie zauważyłam jeziora ${ }^{8}$.

W tym miejscu warto odnieść się do danych geograficznych, by wykazać „wielkość zdrady”, jaką uczyniła w tym wypadku mapa. Powierzchnia przeoczonego jeziora wynosi niecałe 26 tys. $\mathrm{km}^{2}$, a ono samo należy do kom-

5 A. Niewiadomski, Mapa..., s. 8-9.

6 Dotyczy to m.in. mitycznych krain zdających się mieć swoje miejsce na mapie, ale też wszelkich kartograficznych zmyśleń (swoistych „znaków wodnych” świadczących o autorstwie) i pomyłek. Zob. E. Brooke-Hitching, Atlas lądów niebyłych. Największe mity, zmyślenia i pomyłki kartografów, przeł. J. Szczepański, Poznań 2017.

7 Przy czym warto pamiętać, że: „doświadczenie obcości wykazuje zasadnicze podobieństwo do struktury doświadczenia i przeżycia sacrum. Stosunek do tego, co obce ma charakter ambiwalentny; jest połączeniem grozy, niechęci i fascynacji" [Z. Benedyktowicz, Portrety obcego. Od stereotypu do symbolu, Kraków 2000, s. 192].

8 M. Białoszewski, Obmapywanie Europy. AAAmeryka. Ostatnie wiersze, Warszawa 1988, s. 85. 
pleksu Wielkich Jezior Ameryki Północnej ${ }^{9}$. To oczywiście rodzi szereg pytań dotyczących m.in. samego zamieszkiwania. O co innego tu jednak chodzi, a mianowicie o pokazanie, że sama długoletnia obecność nie stwarza pozorów ogarniania (choćby wzrokiem) całego terytorium, do czego prawo rości sobie mapa. Gdy wpadnie ona w niepowołane ręce może stwarzać pozór górowania nad terytorium, a także „władania nim”, skoro przestrzeń zostaje pozbawiona tajemnic, pozornie nam ulega ${ }^{10}$.

Przywoływany tu wcześniej gest wodzenia palcem po mapie czy też swoistego "objeżdżania mapy"11 jest ruchem poprzedzającym wskazanie konkretnego miejsca, potęgującym reisefieber ${ }^{12}$, towarzyszącym niemalże każdej podróży do czasu zatrzymania palca wskazującego na jakimś punkcie barwnej karty ${ }^{13}$. Trafia on jednak czasem na "białą plamę”, jak w przypadku jednego z opowiadań Brunona Schulza, w którym bohater, patrząc na "starą i piękną mapę naszego miasta"14, zauważa, że:

Na tym planie, wykonanym w stylu barokowych prospektów, okolica ulicy Krokodylej świeciła pustą bielą, jaką na kartach geograficznych zwykło się oznaczać okolice podbiegunowe, krainy niezbadane i niepewnej egzystencji ${ }^{15}$.

Tak bliska, bo w końcu "mapa naszego miasta”, a nie innego, obcego, odkrywa przed jej czytelnikiem niezbadany obszar "niepewnej egzystencji”, potęgowany przez sam fakt, że mapa jest „stara”. Być może to właśnie upływ czasu spowodował, że "pusta biel” to w istocie ślady wytarcia fragmentu mapy, a co za tym idzie, bohater nadpisuje „wytarty obszar" swoją opowieścią, w której „rzeczywistość jest cienka jak papier i wszystkimi szparami zdradza swą imitatywność" ${ }^{16}$. Białym terytorium może jednak stać się

9 United States Environmental Protection Agency, The Great Lakes, https://www.epa.gov/ greatlakes [dostęp 27.09.2019].

10 Por. „Mapy są obrazem władzy. Wiedza na temat map sama jest władzą. Kto posiada mapy, ten lepiej orientuje się w organizacji przestrzeni. [...] Mapy gwarantują spojrzenie całościowe, którego brak nam w zgiełku codzienności" [K. Schlögel, W przestrzeni czas czytamy. O historii cywilizacji i geopolityce, przeł. I. Drozdowska, Ł. Musiał, Poznań 2009, s. 247].

11 M. Białoszewski, Obmapywanie..., s. 22.

12 W najprostszym tłumaczeniu przywoływanym przez Słownik języka polskiego PWN [online] to "stan zdenerwowania przed podróżąa". W tłumaczeniu dosłownym "gorączka podróży". Zob. Reisefieber, w: Stownik języka polskiego PWN, www.sjp.pwn.pl [dostęp 10.10.2019].

13 „Karta” czy też „karta geograficzna” to jedno z wielu określeń mapy funkcjonujących w dawnej polszczyźnie, których będę używać w tekście zamiennie, podobnie jak „pejzaż”, czy też "krajobraz". Por. D. Zawadzka, Krajobraz, mapa, pejzaż - powinowactwa romantyczne, w: Geografia i metafora, red. E. Konończuk, E. Nofikow, E. Sidoruk, Białystok 2014.

14 B. Schulz, Ulica krokodyli, w: tegoż, Sklepy cynamonowe, Kraków - Wrocław 1984, s. 73.

15 Tamże, s. 72.

16 Tamże, s. 77. 
każdy obszar nieutekstowiony, nieposiadający licznych reprezentacji tekstowych, będący tym samym terenem słabo opisanym i słabo rozpoznanym ${ }^{17}$. Takie obszary „przyciągają zdobywców, podróżników, turystów. Ci natomiast spisują swoje spostrzeżenia w przekonaniu, że ich słowa wypełnią białe terytorium $[\ldots]^{\prime \prime} 18$.

Tropicielem „białych plam” bez wątpienia staje się Michał Książek ${ }^{19}$, którego opowieści stanowią swoiste "spotkanie na skarpie map i pism" ${ }^{20}$. Co ważniejsze, jego twórczość wpisuje się w ogólne „rozumienie mapy nie tylko jako graficznej reprezentacji przestrzeni, ale także jako tekstu czytanego z perspektywy doświadczenia historycznego, egzystencjalnego czy estetycznego" ${ }^{\prime 21}$. Dzieje się tak za sprawą postrzegania mapy jako kłącza, dzięki czemu zyskuje ona swego rodzaju otwartość i zdolność do stałych modyfikacji ${ }^{22}$. Nie sposób zatem pisać o mapie inaczej niż w poetyce fragmentu, bowiem każde jej otwarcie dostarcza nowych zagięć i śladów, nad którymi warto się pochylić.

Twierdzenie, że mapa stanowi zawsze początek, wydaje się bliskie Michałowi Książkowi, w którego twórczości zajmuje ona miejsce szczególne²3. Stając się w ten sposób początkiem i końcem, a częstokroć i osią narracji,

17 E. Konończuk, Utekstawianie miejsc jako forma praktykowania historii ratowniczej. Przykład Podlasia, „Białostockie Studia Literaturoznawcze” 2016, nr 6, s. 47.

18 Tamże.

19 W odwołaniu do twórczości autora stosuję następujące skróty: D816 - M. Książek, Droga 816, Białystok 2015; J - M. Książek, Jakuck, Wołowiec 2013; NoP - M. Książek, Nauka o ptakach, Białystok 2014; PW - M. Książek, Pótnocny wschód, Białystok 2018.

20 A. Niewiadomski, Mapa..., s. 169.

21 E. Konończuk, Mapa w interdyscyplinarnym dialogu geografii, historii i literatury, „Teksty Drugie" 2011, nr 5, s. 256.

22 „Mapa jest otwarta, daje się połączyć we wszystkich swych wymiarach, daje się zdemontować, odwrócić, podatna jest na stałe modyfikacje. Może zostać rozdarta, odwrócona, może zostać przystosowana do montażu każdego typu. Może być wzięta na warsztat przez jednostkę, grupę, formację społeczną. Można ją narysować na murze, uważać za dzieło sztuki, konstruować jako działanie polityczne albo medytacje" [G. Deleuze, F. Guattari, Kłacze, przeł. B. Banasiak, „Colloquia Communia” 1988, nr 1-3, s. 227].

23 Odnajdujemy ją w zasadzie na każdym kroku. Począwszy od okładek, a skończywszy na treści. W Drodze 816 stanowi ona część nieboskłonu, a także została niejako „wdrukowana” w drogę, co na pierwszy rzut oka przypomina liczne pęknięcia w asfalcie, charakterystyczne dla starych dróg. To skojarzenie nie jest zresztą bezzasadne, bowiem sama droga w twórczości Książka to m.in. „ślad” zapisany na mapie. Trafności temu skojarzeniu dodaje fakt, że w wielu językach, o czym świadczy ich etymologia, 'droga' zrównuje się ze 'śladem' w pierwotnym 
wszak jak mówi sam autor: „mapa przemawia do mnie bardziej niż rzeczywistość" [D816, s. 13]. To stwierdzenie prowadzi bezpośrednio do pytania, czy mapa w twórczości Książka wyrasta z rzeczywistości (stając się próbą jej odwzorowania/naśladowania), czy też to właśnie karta staje się kreatorem widzianego? A co za tym idzie, swoistym przekładem mapy na literaturę? Dokuczliwe zgrzyty między „znakiem a rzeczywistością” [D816, s. 12], tkwienie pomiędzy „mapą a terytorium” [D816, s. 16] stają się podstawą osi narracji Drogi 816 i Jakucka. To właśnie tam m.in. czytamy:

droga [...] biegła w lewo albo w prawo, z mapy zaś wynikało, że powinna iść prosto [...]. Aż pojąłem, że to autor mapy uprościł odwzorowywanie terenu, bo wystarczyło parę kroków w prawo, by znaleźć wspaniałe asfaltowe kontinuum, ciąg dalszy, a nawet futurum, przyszłość [D816, s. 13].

Szybko mijam zabudowany nowymi blokami i sowieckimi dieriewiaszkami odcinek od Lermontowa do przecznicy Oruńskiego, bo nie ma go na starych mapach, powstał zaledwie po wojnie [J, s. 40].

Nabrzeżem można iść stąd na północ, czyli w prawo, w stronę byłego monastyru Zbawiciela, można i na południe, znaczy w lewo, w kierunku Załogu. Warto jednak chwilę postać, bo tu znajduje się początek, a może i środek Jakucka. Cerkiew wznosi się pomiędzy uliczkami Kirowa i Ammosowa, biegnącymi w głąb miasta, gdzie wraz z arteriami Lenina i Jarosławskiego wycinają z przestrzeni kwadrat placu Lenina [...]. Jakuck jakiś taki wystraszony chowa się za nim [pięciobokiem Krużała - dop. I. Ch.]. Na mapie wygląda dużo pewniej [J, s. 23].

Rzeka nie zmieściła się na mapie. Stałem na mostku, rzeka coś chciała powiedzieć, tłumaczyła, perorowała. Cały dzień musiała udawać linię na papierze [PW, s. 27].

Przytoczone powyżej fragmenty świadczą o nieustannej konfrontacji, której dokonuje autor pomiędzy rzeczywistością i jej reprezentacją w postaci mapy. W dodatku kierunki geograficzne zostają zrównane z kierunkami przestrzennymi (północ, czyli prawo; południe, czyli lewo), co może

znaczeniu [zob. A. Brückner, Stownik etymologiczny języka polskiego, Kraków 1927; A. Bańkowski, Etymologiczny słownik języka polskiego, t. 1, Warszawa 2000]. Zarys mapy odnajdujemy również po wewnętrznych stronach książki zarówno Drogi 816 jak i Jakucka. A przede wszystkim odnajdujemy ją w treści - od fragmentów tekstu i rozważań wokół niej, po całe rozdziały poświęcone czytaniu mapy jako swoistej literatury. Ponadto w rozmowie z Piotrem Brysaczem określi Książek mistyczny Wschód jako miejsce „bardziej na prawo na mapie”, co umacnia tezę, że to właśnie ona jest ważnym elementem jego pisarstwa, a także samego doświadczania przestrzeni [zob. M. Książek, Bardziej na prawo na mapie, rozm. P. Brysacz, w: P. Brysacz, Patrząc na wschód. Przestrzeń, człowiek, mistycyzm, Białystok 2013, s. 154]. 
dowodzić co najmniej nakładania się obu tych płaszczyzn (sztuki czytania mapy oraz poruszania się $\mathrm{w}$ terenie), o ile nie ich jedności, wszak uważa się, że mapa "tworzy rzeczywistość, jak i ją reprezentuje" 24. W końcu w drugiej części tryptyku Dzika gęś poeta prosi, by wskazać mu północ:

Bym wiedział gdzie jest góra i dół na mapie

I wszystkie inne tam niewidziane.

[PW, s. 7]

Warto już w tym momencie zasygnalizować, że w przypadku twórczości Książka niektóre opisy rzeczywistości wywodzą się wprost z mapy, a nie realnego doświadczenia przestrzeni. Nie powinno zatem dziwić, że kierunek północny raz jest utożsamiany $\mathrm{z}$ "prawą stroną", a innym razem z "górą" na mapie.

Ufający bardziej mapie niż rzeczywistości autor pomija w swojej wędrówce te fragmenty, których „nie ma na starych mapach”, uznając przy tym mapę za samą metaforę widoku [J, s. 31]. Każda niezgodność jest wynikiem „uproszczenia odwzorowywania terenu”, które powoduje chwilowy brak ciągłości narracji - zarówno jej "kontinuum” jak i "futurum”, przy czym należy pamiętać, że uproszczenie, a tym samym zakłócenie narracji, przypisane zostanie autorowi mapy. Jednak niedokładność mapy nie jest tym samym, co ludzka niedokładność, a ponadto obie te niedokładności nie oddziałują na siebie ${ }^{25}$.

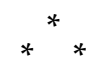

Czy istnieje jednak mapa doskonała? Sytuację powstania takiej karty ilustruje w swoim krótkim opowiadaniu Jorge Luis Borges:

W owym Cesarstwie Sztuka Kartografii osiągnęła taką doskonałość, że Mapa jednej tylko Prowincji zajmowała całe Miasto, a Mapa Cesarstwa całą prowincję [...]. Mniej Oddane Studiom Kartografii Następne Pokolenia doszły do wniosku, że ta obszerna Mapa jest Nieużyteczna i nie bez Bezbożności oddały ją na Pastwę Słońca i Zim. Na Pustyniach Zachodu zachowały się rozczłonkowane Ruiny Mapy ${ }^{26}$.

\footnotetext{
24 E. Rybicka, Geopoetyka..., s. 148.

25 Zob. „Nigdy nie podejrzewałem, że ludzie mogliby być właściwymi twórcami map, to raczej mapy tworzą ludzi, a ludzka niedoskonałość i niedokładność mapy wcale nie przekładają się na niedoskonałość map" [A. Niewiadomski, Mapa..., s. 27].

26 J. L. Borges, O ścisłości w nauce, w: tegoż, Powszechna historia nikczemności, przeł. A. Zembrzuski, A. Sobol-Jurczykowski, Warszawa 1982, s. 87.
} 
Doskonała mapa, będąca tworem doskonałych kartografów, dość szybko staje się „Nieużyteczna”, choć w parze za jej doskonałością szła i dokładność. Doskonali kartografowie tworzą doskonałe mapy, które nie spełniają jednak swej podstawowej funkcji, którą jest pragmatyzm. Dodatkowo wykonana wiernie w skali 1:1 zawłaszcza terytorium, unicestwia istnienie cesarstwa jako takiego ${ }^{27}$. Zagospodarowana $\mathrm{w}$ ten sposób przestrzeń nie zostawia pola dla czytelnika i jego doświadczeń, miejsce to zostaje wypełnione dopiero pomiędzy „Ruinami Mapy”, pomiędzy jej szczelinami. Nie bez powodu zatem Książek będzie „przyglądał się mapom prawie jak Stwórca” [NoP, s. 55], będąc przy tym "trochę wszechmogący, trochę wszechobecny, / jakiś taki transcendentalny” [NoP, s. 55]. To pozwala na "przyjęcie punktu widzenia Boga współuczestniczącego u boku człowieka w (re)konstrukcji świata" ${ }^{28}$. Każde rozpostarcie mapy jest już ingerencją w jej strukturę, a także próbą rekonstrukcji świata, zaś w przypadku Książka dodatkowo przekładem mapy na literaturę, tym samym trzeba pamiętać, że:

Od tej pory to mapa poprzedza terytorium - precesja symulakrów - to ona tworzy terytorium i, by odwołać się ponownie do opowieści Borgesa, dziś to strzępy terytorium gniją powoli na płaszczyźnie mapy. To szczątki rzeczywistości, a nie mapy, przetrwały tu i tam ${ }^{29}$.

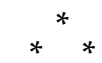

Wspominana wszędobylskość/wszechobecność przypisywana Stwórcy mapy, współbudującemu przestrzeń, odsyła do ostatniego wiersza Wisławy Szymborskiej zatytułowanego Mapa, w którym miniaturowy świat przedstawiony na zadrukowanej karcie zdaje się być "na wyciągnięcie ręki” oraz bezpieczny, wszak:

Wszystko tu małe, dostępne i bliskie.

Mogę końcem paznokcia przyciskać wulkany,

bieguny głaskać bez grubych rękawic,

mogę jednym spojrzeniem

ogarnąć każdą pustynię

razem $\mathrm{z}$ obecną tuż tuż obok rzeką ${ }^{30}$.

\footnotetext{
27 U. Eco, O tym, że nie da się sporządzić mapy cesarstwa w skali 1:1, w: tegoż, Diariusz niewielki, przeł. A. Szymanowski, Kraków 1995, s. 83-88.

28 K. Schlögel, W przestrzeni..., s. 72.

29 J. Baudrillard, Symulakry i symulacja, przeł. S. Królak, Warszawa 2005, s. 6.

30 W. Szymborska, Mapa, w: tejże, Wystarczy, Kraków 2012, s. 21.
} 
W całkiem podobny sposób mapowy świat będzie jawił się Michałowi Książkowi:

Mapy zawsze pokazują miejsca
niezwykle bezpieczne.

W ich rzekach nie można utonąć, nie grozi od nich powódź.

Na drogach nie można zabłądzić, zawsze są puste i proste,

a spinki mostów krzepko łączą

kolejne fragmenty rzeczywistości.

Na mapach nigdy nie wieje,

toteż drzewa i trawy rozsiewają papierową woń spokoju.

Nie pada deszcz,

bo przecież świat mógłby rozmoknąć.

Panuje tam cisza

jak drobnym makiem zasiał.

Czasami myślę, że dobrze byłoby ją zakłócić

i w odpowiedniej skali

stać się postacią jednej z legend.

[NoP, s. 51]

W obu tych przypadkach mapa staje się synonimem - dostępności, bliskości i bezpieczeństwa. Można rzec, że cały świat jest na wyciągnięcie ręki tego, kto po niego sięga. Wszakże w podróż „palcem po mapie” nie zostaje wpisany strach, bowiem ruch ten nie tworzy ryzyka zatonięcia w oceanie, gdy tylko palec nieco się obsunie, wyjdzie poza kontur oznaczonego lądu ${ }^{31}$.

31 W tym miejscu można by się zastanowić nad znaczeniem rzeki dla mapy, która zdaje się być jednym $\mathrm{z}$ koniecznych elementów, aby mapa jako taka w ogóle mogła zaistnieć, wszak: „Zespół elementów treści na różnych mapach nie jest jednakowy [...]. Jednak jeden element, a mianowicie wody (linie brzegowe mórz i jezior, sieć rzeczna), jest potrzebny na każdej mapie; jest on ważny dla lokalizacji pozostałych elementów jej treści" [cyt. za A. Niewiadomski, Mapa..., s. 68]. Nie pozostaje to bez znaczenia i dla samego Książka, którego wędrówka tytułową drogą 816 odbywa się wzdłuż rzeki, stanowiącej jedną z granic mentalnych, ale też i tych zapisanych na mapie, tworzących granice państwowe. W przypadku Jakucka przetok „wyznacza wątłą granicę pomiędzy miejscem a pustką" [J, s. 21], ale też sama obecność wody staje się dopełnieniem krajobrazu, wszak: „Miasto zyskało na parę dni odbicie w wodzie i w końcu jego widok jest kompletny. Jak na starych kozackich mapach" (J, s. 54). W innym fragmencie rzeka staje się alegorią czasu, ale też wspominanym wcześniej punktem orientacyjnym, gdyż: 
Tym bardziej intrygująca staje się część ostatnia, w której poeta wyraża chęć zakłócenia przestrzeni, czy też właściwie "porządku” mapy, chcąc się w nią wpisać, zostać w niej uwzględniony - stać się legendą, dodajmy, „w odpowiedniej skali". Trzeba przyznać, że odważne to marzenie i zarazem niedorzeczne, pełne pychy. Nietrudno zgodzić się w tym miejscu z Andrzejem Niewiadomskim, uważającym, że:

bardziej niedorzeczne jest szukanie , ja" w świecie mapy. Wielokrotnie, oglądając mapy, widziałem tam przedziwne rzeczy, ale nigdy nie doszukiwałem się ani ,ja zmniejszonego", ani ,ja innego". "Ja" w ogóle nie mieści się ani w największej, ani najmniejszej skali. Tak jak nie mieści się pchła na psie, i nie chodzi tu o niedokładność, idzie o zupełnie inny typ relacji. Perspektywa personalna prowadzi ku nieuzasadnionej pysze, a wszystkie próby włączenia ludzi w mapę w taki sposób, by byli widoczni, kończą się klęską ${ }^{32}$.

Potwierdzeniem poniesionej klęski jest cytowane wcześniej opowiadanie Borgesa. Brak ludzkiej obecności, swoista pustka (biała plama) na mapie stanowić będzie granicę między tym, co realne a wyobrażone. Gdy autor zaczyna czytać mapę jako rzeczywistość33, powstaje oczywiste napięcie, wspominany tu niejednokrotnie zgrzyt: „Horodło było puste, jak na mapie” [D816, s. 19]. W celu egzemplifikacji wspomnianego wcześniej „przekładu" mapy na literaturę, warto przywołać jeden z rozdziałów Drogi 816, zatytułowany właśnie Mapa, w którym czytamy:

Gdzieś go już widziałem z oddali - ten Bug. Widziałem to, co gospodarz, wopista i sklepowa. Taką rzekę z daleka, zakręcającą na zachód. Płynęła powoli, jak zmęczona, jakby nie mogła przeminąć. A tak stara, że ludzie zapomnieli, od czego tak ją nazwali. I tuż przed zaśnięciem przypomniałem sobie, że to było na mapie. Na mapie $z$ napisem JANÓW PODLASKI, w skali 1:100000, czyli centymetr na papierze, kilometr $\mathrm{w}$ terenie [D816, s. 86].

W powyższym fragmencie widoczne staje się to oscylowanie między „znakiem a rzeczywistością”, na które niejednokrotnie w swojej twórczości zwróci jeszcze uwagę Książek. W rozmowie z Piotrem Brysaczem przyznaje:

\footnotetext{
„Zabłądzić tu trudno, bo gdziekolwiek pójść, trafi się na Lenę albo wysoki zachodni kraniec doliny, skąd widać świat jak na mapie" [J, s. 191]. Nietrudno więc powtórzyć za Andrzejem Niewiadomskim, że „większym sojusznikiem mapy niż przewodnik jest locja” [zob. A. Niewiadomski, Mapa..., s. 68].

32 A. Niewiadomski, Mapa ..., s. 25.

33 To lektura mapy, o której Elżbieta Konończuk napisze, że: „ma na celu dotarcie do treści, o których ona [mapa - przyp. I. Ch.] milczy, bądź odnoszących się do indywidualnych doświadczeń jej posiadacza" [E. Konończuk, Mapy w interdyscyplinarnym...., s. 257].
} 
pochłaniam je [mapy - dop. I. Ch.] jak książki. Patrząc na topografię w skali kilometra potrafię zobaczyć widok $\mathrm{w}$ terenie. Prawie jak na zdjęciu. No i wystarczy jedno spojrzenie i jestem wszędzie - $\mathrm{i} w$ dolinie, na stoku, na szczycie, a za chwilę w ujściu rzeki. Terytorium, mapa, przestrzeń i widok ${ }^{34}$.

W powyższych fragmentach autor zdradza umiejętność nadpisywania obszarów, czy też właściwie ich utekstawiania i kreowania widoków na podstawie samej mapy. Wędrówka autora i co za tym idzie - czytelnika, nie zawsze odbywa się $\mathrm{w}$ terenie, $\mathrm{w}$ przestrzeni. Czasami zostaje ograniczona przez krawędzie mapy, poza które autor nie wychodzi, i których nie docieka.

Oddając się uważnej lekturze Drogi 816, czytelnik niejednokrotnie natknie się na fragmenty, w których wspomniana wcześniej mapa i przestrzeń zdają się być sobie "nie po drodze”, a także „nie w czasie”, powodując rozdźwięk, czy też właściwie „zdziwienie na granicy protestu” [D816, s. 12]. To poczucie "bycia nie na miejscu" będzie towarzyszyć poecie za każdym razem, gdy spróbuje on skonfrontować swoje położenie z mapą. Jak na przykład podczas spoglądania na mapy Jakucji:

Dziwić się,

Że mnie na nich nie ma

Przeglądam znane mi drogi,

lustruję wzgórza, badam rzeki.

Na koniec sprawdzam w legendzie:

Nie ma mnie.

$$
\text { [NoT, s. 39] }
$$

W następnych strofach utworu autor wymienia kolejno „zasługi”, które powinny wpisać go $\mathrm{w}$ legendę, czy też właściwie uczynić go legendą (a w szerszej perspektywie - człowiekiem legendą; por. np. poszukiwanie okruchów neolitu nad Leną). Sama jego obecność pomiędzy wsią Płatków a Starą Gaćą powinna być „wystarczająca” do „wpisania się w topografię”, wszak mowa tu o miejscu, które (jak notuje w Jakucku):

Z północy na południe ma dwa tysiące kilometrów, a ze wschodu na zachód trzeba dodać jeszcze trzysta, [...] więcej tu zwierząt niż ludzi. A na wschodzie ma zaledwie dwie drogi. Nie dość, że donikąd, to jeszcze nie zawsze przejezdne [J, s. 13-14].

34 P. Brysacz: Patrzac na.., s. 169. 
Mapa Jakucji staje się zatem bardziej barwną kartą niż starannie opracowanym rysem topograficznym „zamkniętym” na kartce papieru, która w tym przypadku mogłaby jeszcze wiele pomieścić35. Ostatecznie jednak uznana zostaje "wielkość mapy", nieskorość do mieszania porządków - jak to ujmuje Szymborska - „świata / nie z tego świata” ${ }^{36}$. Michał Książek uzna, że:

Mapy noszą tylko ślady wędrówek,

ślady śniadania, wiersza,

licznych przetarć i zagięć.

[NoT, s. 39]

I jeżeli coś je łączy, jeśli coś spaja znak z rzeczywistością to fakt, że mapa obdarzona licznymi przetarciami i zgięciami, czasem zagina te porządki, a zwłaszcza wtedy, gdy w jednym z przetarć spojrzenie zostaje na dłużej, "jak stopa / w dziurawym moście” [Not, s. 39]. Trafnie zatem zauważa Andrzej Niewiadomski, „mapa zarysowuje granice, ale sama ich nie przestrzega" ${ }^{37}$. Powyższe przykłady korespondują z tezą Briana Harleya, którego zdaniem "mapy noszące ślady podróży odbywanych $\mathrm{z}$ ich pomocą są źródłem wspomnień, a nawet szczególną, w swojej graficznej postaci, opowieścią o podróżach, o pejzażach, które zachwycały podczas tych podróży, o wydarzeniach, które miały w nich miejsce, oraz o towarzyszach wędrówek" ${ }^{38}$. W tym ujęciu mapa staje się nie tyle przewodnikiem, co rzeczą/miejscem, w którym zachowane zostaje indywidualne doświadczenie przestrzenne.

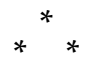

Swoisty „przekład mapy na literaturę", wspominany tu już niejednokrotnie, znajdzie swoje rozwinięcie w ostatnim z trzech „mapowych” wierszy Michała Książka, w którym to pisarz stwierdzi:

35 Portret miasta skreślony przez autora aż domaga się utekstowienia, nadania mu wyraźnych kształtów, konturów, wszak: „kiedy mgła nieco zrzednie, widać, że miasto wygląda jak niedbale skreślony szkic albo stary sztych, na którym tło zajmuje pierwszy plan. Linie niedokończone, prostokąty niedomknięte. Rządzi wszechobecna niedoskonałość, niedosyt geometrii i światła. Słońce niby świeci, ale jak z zaświatów, właściwie to skąpa poświata, a nie światło. A bez światła - etymologicznie rzecz biorąc - świata nie ma" [J, s. 116]. Oraz "Jakuck zawinięty jest w biel jak w papier. Omotany horyzontem jak mocnym sznurkiem" [J, s. 117].

36 W. Szymborska, Mapa, s. 21.

37 A. Niewiadomski, Mapa..., s. 12.

38 Tezę tę przytaczam za: E. Konończuk, Mapy w interdyscyplinarnym..., s. 256. 
Mapy to jednak literatura.

Czwarty rodzaj

po epice, liryce i dramacie.

[NoT, s. 55]

Stwierdzenie to zestawione $\mathrm{z}$ fragmentem rozdziału rozpoczynającego Jakuck, zatytułowanego Mapa, ukazuje, że to właśnie ona, podobnie zresztą jak u Andrzeja Niewiadomskiego, jest zawsze początkiem, a także „wdziera się niedostrzegalnie do świata literatury" ${ }^{39}$. Wspomniany fragment to swoiście zobrazowany akt przekładu mapy na język literatury, czytamy w nim bowiem:

Centralna Jakucja, czyli międzyrzecze Wiluja, Leny i Ałdanu, wygląda na mapie jak manowce na końcu świata. Od północy i wschodu zamyka ją klamra szczytów Gór Wierchojańskich, Gór Rzeki Głębokiej i Wielkiej Przeszkody [...]. Rzeki jakuckich manowców przypominały zesłanemu tu Wacławowi Sieroszewskiemu bujną koronę drzewa, które pniem Leny uchodzi na północ, póki korzeniami delty nie wrośnie w Ocean Lodowaty [...]. Gałęzie drzewa - idąc za spojrzeniem pisarza - okalają łańcuchy górskie, pod których naporem konary rzeki wpadają do Leny [...]. Ja zaś widzę w jej zlewni poroże starego renifera, co ma łeb wielki jak Morze Łaptiewów i wieńcem zaplątał się w zwojach poziomnic [...]. Dalej szeroka szyja i kłąb rozciągają się jak Morze Wschodniosyberyjskie aż po ujście Kołymy i Czukotkę. Byk tratuje północne niebo, galopując do góry nogami, i zabiera się do pożarcia Tajmyru. Żeby jednak zobaczyć go na mapie Jakucji, trzeba parę razy samemu obudzić się z reniferową tyką między żebrami albo mieć mapę sięgającą siedemdziesiątego drugiego stopnia szerokości północnej [J, s. 9-10].

Za punkt wspólny mapy i literatury można uznać przekłamanie rzeczywistości, jakim obie ulegają. Przypomnijmy, że w kontekście mapy nie powinno się mówić o nieudolnym naśladowaniu, a zwłaszcza wtedy, gdy, powtórzmy: „zarysowuje granice, ale sama ich nie przestrzega" ${ }^{40}$. Mapa bowiem zawsze jest wyimkiem jakiegoś obrazu rzeczywistości, niebędącym nigdy „wersją ostateczną”. Dlaczego jednak mapa staje się w ujęciu Książka literaturą? Mówi on:

W żadnej powieści, pieśni czy komedii przestrzeń nie została tak dobrze uchwycona, jak na mapie.

\footnotetext{
39 A. Niewiadomski, Mapa..., s. 169.

40 Tamże, s. 12.
} 
Nigdzie indziej nie schwytano czasu

na gorącym uczynku,

jak tylko na planie miasta, którego już nie ma.

[NoT, s. 55]

Mapa zatem staje się literaturą, jeśli uznamy, że do głównych jej zdań należy - ocalenie - zachowanie stanu obecnego i pamięci po dawnym porządku ${ }^{41}$. Jeśli jej czasem jest przeszłość i teraźniejszość. W tym kontekście to wpisanie się $\mathrm{w}$ mapę, do którego dążył we wcześniej cytowanych utworach poeta, zyska inną wymowę. Michał Książek zdaje się mówić, że przyszłość nie przechowa "pomnika trwalszego niż ze spiżu”, jeśli ślad po poecie nie zostanie wpisany - paradoksalnie - $\mathrm{w}$ podatną na przetarcia i zniszczenie mapę, a więc i topografie miast(a). Poeta przygląda się:

[...] mapom prawie jak Stwórca trochę wszechmogący, trochę wszechobecny. Jakiś taki transcendentalny.

[NoT, s. 55]

Przypomina zatem - na swój sposób - „Stwórcę map”. Przekształcając ich strukturę w tekst, w obraz literacki, niejako "mówiąc ich ustami", stoi w punkcie styku literatury i mapy, przeciągając tę drugą na obszar tej pierwszej. Autor, odczuwający "dokuczliwy zgrzyt między znakiem a rzeczywistością" [D816, s. 12], pozostaje w przygranicznej strefie, bo tylko w niej możliwe jest uchwycenie mapy przenikającej do narracji o doświadczaniu rzeczywistości. Jak zauważa cytowany już wcześniej badacz:

Trzeba przebywać w przygranicznej strefie, choćby na sfałszowanych papierach. Nie na wariackich. W strefie pozwalającej przynajmniej zbliżyć się do punktu rychło przechodzącego w teksturę mapy. By zadeklarować: „Oto, będąc przy

${ }^{41}$ Całkiem podobną wizję zadań mapy odnajdziemy w twórczości Andrzeja Stasiuka, dla którego „«Rozkład jazdy na liniach autobusowych, okrętowych, kolejowych i lotniczych» był próbą odwzorowania świata w skali 1:1, próbą stworzenia go na nowo. Moja mapa natomiast, jak zresztą każda stara mapa, ocala świat, a jednocześnie pokazuje jego rozpad, jego przemijanie. Patrząc na nią, spoglądam w nicość, którą moja wyobraźnia chce za wszelką cenę wypełnić" [A. Stasiuk, Fado, Wołowiec 2006, s. 38]. Takich paraleli można by wskazać więcej, a nawet wykazać, że Książek niejako czerpie z twórczości Stasiuka, który jako pierwszy pisał o drodze 816 w kontekście literackim: „Ilekroć słyszę biadolenie o braku polskiej powieści na miarę czasów oraz możliwości, przychodzi mi do głowy droga numer 816" [A. Stasiuk, Droga 816, w: tegoż, Nie ma ekspresów przy żóttych drogach, Wołowiec 2013]. Co też później znalazło rozwinięcie $\mathrm{w}$ twórczości tego drugiego. 
zdrowych zmysłach, wiem o mapie tyle, że mogę stać się choćby przez moment jej ustami; jest jednak wiele rzeczy, których ona powiedzieć mi nie pozwoli" ${ }^{42}$.

W swojej twórczości zarówno reporterskiej, jak i poetyckiej ${ }^{43}$ Książek nieustannie balansuje między światem mapy oraz światem rzeczywistym, łącząc je w narracji o swoich podróżach i obserwacjach. Daje temu wyraz również w poniższym fragmencie:

Znów tkwiłem między mapą a terytorium, niby wiadomo gdzie to jest, ale nie wszystko wydawało się jasne. Towarzyszyło temu uczucie pokrewne schizofrenii, rozdwojenia jaźni, jakby istniało dwóch idących. Takie trwanie w rozkroku, niezdecydowanie między światami. Dysonans poznawczy czy coś [...]. Mapa stanowiła doskonałą ideę świata wokół i, koniec końców, pozwalała się odnaleźć. Nie inaczej, między mapą a terytorium [D816, s. 16].

I to właśnie stanie "pomiędzy" 4 , swoiste zaklinowanie się między realnym a wyobrażonym, staje się pretekstem do snucia nadbużańskich opowieści w Drodze 816, m.in. o "dziku wielkim jak fiat 125p” [D816, s. 53] czy też „bobrze, który zagryzł wędkarza” [D816, s. 53]. To wszystko dzieje się na drodze, jeśli wierzyć mapie, z Hrubieszowa do Białowieży, jeśli znów tekstowi, z Lublina do Białowieży. Z kolei w Jakucku sporządzane mapy, z którymi „w ciągu kilku minut” autor był ,już na wzgórzu”, unaoczniają wzajemne przenikanie się mapy i terytorium, wszak „dystans między słowem a światem znikł zupełnie, a spojrzenie znalazło obraz" [J, s. 198]. W ten sposób wpisany (czy też nie) w legendę mapy, w topografię miejsca, Michał Książek pozostanie piewcą mapy ${ }^{45}$, która przemawia do niego „bardziej niż rzeczywistość". A przy tym należy pamiętać, że w gruncie rzeczy:

\footnotetext{
42 A. Niewiadomski, Mapa..., s. 46.

$43 \mathrm{~W}$ twórczości autora często odnaleźć można pokrewne fragmenty zapisane przy użyciu różnych rodzajów literackich, co umożliwia czynione m.in. w tym szkicu bezpośrednie zestawienia utworów poetyckich z reportażami. Zresztą sam autor komentując swoją twórczość w rozmowie z Adamem Robińskim, przyznaje: „Wiersz czy reportaż... Jeśli mam wejść do środka, do sedna, to jaka różnica drzwiami czy też oknem?" [M. Książek, Zmysty wypasam na tąkach. Z Michałem Ksiażkiem rozmawia Adam Robiński, „Tygodnik Powszechny”, 9 kwietnia 2016, https://www.tygodnikpowszechny.pl/zmysly-wypasam-na-lakach-33214 [dostęp 01.06.2020].

44 Na ostatnich stronach Jakucka autor zanotuje: „Początek i koniec plączą się, tworząc miejsca" [J, s. 232]. Strefa "pomiędzy” staje się niczym innym jak pomieszaniem zarówno porządków świata rzeczywistego, jak i świata mapy wraz z początkiem i końcem samej wyprawy, narracji o niej, czy też towarzyszących jej licznym emocjom.

45 Autor poświęca również jeden ze swoich wierszy książkom, wśród których to właśnie „mapy mają się [...] dobrze”, ponadto „wędruje po grzbietach książek. // Co półka, to horyzont: / Jakucja, Syberia, / Mandżuria, Chiny / i kurz jak na drodze. // Ich geometria i geografia / to jedyny porządek / w rzeczywistości [...]" [M. Książek, Nauka o..., s. 38].
} 
Nie chodzi tu już jednak o mapę, ani terytorium. Coś zniknęło, a tym czymś jest istotna różnica między jednym i drugim, która stanowiła o uroku abstrakcji. Gdyż to różnica stanowi o poezji mapy i uroku terytorium, o magii pojęcia i powabie rzeczywistości ${ }^{46}$.

\section{Bibliografia}

Bańkowski Andrzej (2000), Etymologiczny słownik języka polskiego, t. 1, Warszawa: Wydawnictwo Naukowe PWN.

Baudrillard Jean (2005), Symulakry i symulacja, przeł. S. Królak, Warszawa: Sic!.

Benedyktowicz Zbigniew (2000), Portrety "obcego". Od stereotypu do symbolu, Kraków: Wydawnictwo Uniwersytetu Jagiellońskiego.

Białoszewski Miron (1988), Obmapywanie Europy. AAAmeryka. Ostatnie wiersze, Warszawa: Państwowy Instytut Wydawniczy.

Borges Jorge Louis (1982), Powszechna historia nikczemności, wyd. 2, przeł. S. Zembrzuski, A. Sobol-Jurczykowski, Warszawa: Państwowy Instytut Wydawniczy.

Brooke-Hitching Edward (2017), Atlas lądów niebylych. Największe mity, zmyślenia i pomyłki kartografów, przeł. J. Szczepański, Poznań: Dom Wydawniczy Rebis.

Brückner Aleksander (1927), Słownik etymologiczny języka polskiego, Kraków: Krakowska Spółka Wydawnicza.

Brysacz Piotr (2013), Patrząc na wschód. Przestrzeń, człowiek, mistycyzm, Białystok: Fundacja Sąsiedzi.

Deleuze Gelles, Guattari Félix (1988), Kłącze, przeł. B. Banasiak, „Colloquia Communia", nr 1-3, s. 221-238.

Eco Umberto (1995), Diariusz najmniejszy, przeł. A. Szymanowski, Kraków: Znak.

Geografia i metafora (2014), red. E. Konończuk, E. Nofikow, E. Sidoruk, Białystok 2014, s. 11-29.

Kadłubek Zbigniew (2018), Mapa, czyli świat na wynos, „Znak”, nr 758-759, s. 6-11.

Konończuk Elżbieta (2011), Mapa w interdyscyplinarnym dialogu geografii, historii $i$ literatury, "Teksty Drugie”, nr 5, s. 255-264.

Konończuk Elżbieta (2016), Utekstawianie miejsc jako forma praktykowania historii ratowniczej. Przykład Podlasia, "Białostockie Studia Literaturoznawcze”, nr 8, s. 33-49.

Książek Michał (2013), Jakuck, Wołowiec: Wydawnictwo Czarne.

Książek Michał (2014), Nauka o ptakach, Białystok: Fundacja Sąsiedzi.

Książek Michał (2015), Droga 816, Białystok: Fundacja Sąsiedzi.

Książek Michał (2016), Zmysły wypasam na łąkach. Z Michałem Książkiem rozmawia Adam Robinski, „Tygodnik Powszechny”, 9 kwietnia, https://www.tygodnikpowszech ny.pl/zmysly-wypasam-na-lakach-33214 [dostęp 01.06.2020].

Książek Michał (2018), Kiedy rzeka mówi: wypij mnie, „Książki”, nr 6, s. 48-49.

Książek Michał (2018), Północny wschód, Białystok: Fundacja Sąsiedzi.

${ }^{46}$ J. Baudrillard, Symulakry..., s. 6. 
Niewiadomski Andrzej (2012), Mapa. Prolegomena, Lublin: Ośrodek Brama Grodzka - Teatr NN.

Rybicka Elżbieta (2014), Geopoetyka. Przestrzeń i miejsce we współczesnych teoriach i praktykach literackich, Kraków: Universitas.

Schlögel Karl (2009), W przestrzeni czas czytamy. O historii cywilizacji i geopolityce, przeł. I. Drozdowska, Ł. Musiał, Poznań: Wydawnictwo Poznańskie.

Schulz Bruno (1984), Sklepy cynamonowe, Kraków - Wrocław: Wydawnictwo Literackie.

Stasiuk Andrzej (2006), Fado, Wołowiec: Wydawnictwo Czarne.

Stasiuk Andrzej (2013), Nie ma ekspresów przy żóttych drogach, Wołowiec: Wydawnictwo Czarne.

Szymborska Wisława (2012), Wystarczy, Kraków: Wydawnictwo a5.

\title{
"On the Escarpment of Maps and Writings": A Few Remarks on the Margin of Michał Książek's Works
}

\begin{abstract}
The article discusses the functions of the map in the journalism and poetry of Michał Książek (Droga 816, Jakuck, Nauka o ptakach, Pótnocny wschód). The author asserts that the map creates multiple tensions between the sign and reality and releases the emotions which accompany the journey, both in space and time. Książek constantly seeks correspondence between the world of the map and reality, which he merges in his travel narratives and observations.
\end{abstract}

Keywords: map, space, place, representation, emotions 